\title{
DNA variations of the green toad Pseudepidalea viridis (syn. Bufo viridis) from various habitats
}

\author{
Gad Degani ${ }^{1,2 *}$, Tali Goldberg ${ }^{2,4}$, Avital Gasith $^{3}$, Eldad Elron ${ }^{3}$ and Eviatar Nevo ${ }^{4}$
}

\begin{abstract}
Background: The present study examined genetic variations of the green toad Pseudepidalea viridis from different breeding sites throughout Israel and in Egypt, Turkey, Iran, and Germany (out-groups).

Results: Comparison of Cyt $b$ and D-loop fragments from Israeli sites with those from the four out-groups showed that analysis of molecular variance (AMOVA) was greatest among regions. Values of proportion of the total genetic variance among regions (PhiRT) in Israeli sites were relatively low and not statistically significant. A cluster analysis of RAPD for classifying $P$. viridis revealed a subgroup comprising seven northernmost populations and three populations near the southern and eastern deserts surrounding Israel. AFLP analysis defined all individuals in a single cluster. Variations in P. viridis according to AMOVA test of Israeli sites using GenAl were $2 \%$ among regions, $8 \%$ among populations, and $90 \%$ within populations.
\end{abstract}

Conclusions: These findings support the hypothesis that various ecological conditions in a relatively small area have little effect on genetic variations.

Keywords: Amphibians; AFLP; RAPD; Mitochondrial genes

\section{Background}

The green toad Pseudepidalea viridis is one of the most widespread Old World amphibian species. It belongs to the family Bufonidae, which is one of the most speciesrich (with more than 350 species) and widely distributed amphibian families. $P$. viridis lives in various habitats (Cummingham and Cherry 2004) and is distributed throughout Europe (including the southern tip of Sweden but excluding the rest of Fennoscandia, the British Isles, and western Europe west of the Rhine River and south of Sicily and Crete) and to Kazakhstan, Tajikistan, and Kerman Province of Iran (and likely adjacent to Afghanistan and the Altai mountains in Russia, Mongolia, and Western Xinjiang, China) in the east. Isolated populations exist on Balearic Island, Sardinia, and Corsica; in northern Africa, it is present on the coastal area of northwestern Sahara, from western Morocco and Algeria (including the Ahaggar Massif) to western Libya. Finally, it is found in southwestern Asia

\footnotetext{
* Correspondence: gad@migal.org.il

'MIGAL, Galilee Technology Center, Kiryat Shmona 11016, Israel

${ }^{2}$ School of Science and Technology, Tel-Hai College, Upper Galilee 12210, Israel

Full list of author information is available at the end of the article
}

and the Arabian Peninsula in the southern Hadramaut (Duellman 1993). P. viridis is a prolonged-breeder anuran that typically utilizes temporary, shallow water bodies (Degani and Kaplan 1999; Sicilia et al. 2007; Goldberg et al. 2009a; Disi and Amr 2010) and can withstand a salinity of 26 ppt (Ren et al. 2009). The quality of such habitats may show major temporal changes. Water quality becomes more accentuated when a pond is drying up, but tadpoles can respond to different periods of water availability in winter ponds by accelerating metamorphosis (Degani 1982, 1986; Newman 1992; Blaustein and Margalit 1995; Goldberg et al. 2009a) and by differences in the clutch mass and female body size (Baskale et al. 2011). In Israel, P. viridis is distributed throughout the country in different types of areas, including the desert (Nevo et al. 1975; Blaustein and Margalit 1995; Goldberg et al. 2011). These P. viridis populations live under extreme ecological conditions. Spatially, they range along ecological gradients of increasing aridity, southwards as well as eastwards, approaching the southern and eastern deserts surrounding Israel. $P$. viridis tadpoles metamorphose in winter and spring and are thus exposed to adverse and dry environments in Israel (Degani and Kaplan 1999; Katzmann 
et al. 2003). Adults of $P$. viridis are active during summer nights and travel long distances on land in search of food or to mate in ponds during the breeding season; thus, they exposed to environmental pressures. Many aspects of the Bufonidae species have been studied, including their phylogeny (Liu et al. 2000) and taxonomy (Matsui 1986). Dessauer et al. (1975) studied allozymic variations in proteins encoded by 26 loci that were analyzed electrophoretically from 517 specimens of P. viridis of 11 populations from Israel and 1 population from Vis Island in the Adriatic Sea. Values of three genetic parameters, the mean number of alleles per locus $(A)$, the mean proportion of loci polymorphism per population $(P)$, and the mean number of heterozygous loci per individual $(H)$, were very high. Central and marginal mainland populations were only slightly more variable than desert isolates but were much more variable than the Vis Island population. The observed genetic variation suggested selection for heterozygosity as an adaptive strategy in the ecologically variable environments in which green toads live.

Nevo et al. (1975) studied the rich genetic variations of $P$. viridis as a test of natural selection. Significant heterozygosity $(H)$ between loci was found for all alleles and for each of the four major classes of proteins tested, which may be taken as evidence of selection. Both uniform and diversifying selections were suggested. The general pattern of high heterozygosity in $P$. viridis (average $H=0.133$; range $0.105 \sim 0159$ ) is best explained as an adaptive strategy in heterogeneous and

Table 1 Latitude and longitude of $\boldsymbol{P}$. viridis populations from 30 breeding sites

\begin{tabular}{|c|c|c|c|c|}
\hline \multirow{2}{*}{$\begin{array}{l}\text { Site and zone } \\
\text { Northern Israel }\end{array}$} & \multirow[b]{2}{*}{1} & \multirow{2}{*}{ Israel_Hermon } & \multirow{2}{*}{$\begin{array}{l}\text { Longitude } \\
33^{\circ} 17^{\prime} 29^{\prime \prime} \mathrm{N}\end{array}$} & \multirow{2}{*}{$\begin{array}{c}\text { Latitude } \\
35^{\circ} 45^{\prime} 13^{\prime \prime} \mathrm{E}\end{array}$} \\
\hline & & & & \\
\hline & 2 & Israel_Masade & $33^{\circ} 13^{\prime} 59^{\prime \prime N}$ & $35^{\circ} 45^{\prime} 09^{\prime \prime} \mathrm{E}$ \\
\hline & 3 & Israel_Orvin & $33^{\circ} 09^{\prime} 29^{\prime \prime N}$ & $35^{\circ} 40^{\prime} 15^{\prime \prime} \mathrm{E}$ \\
\hline & 4 & Israel_Nahalit & $33^{\circ} 04^{\prime} 56^{\prime \prime} \mathrm{N}$ & $35^{\circ} 27^{\prime} 48^{\prime \prime} \mathrm{E}$ \\
\hline & 5 & Israel_Fara & $33^{\circ} 03^{\prime} 58^{\prime \prime} \mathrm{N}$ & $35^{\circ} 27^{\prime} 39^{\prime \prime} \mathrm{E}$ \\
\hline & 6 & Israel_Matityahu & $33^{\circ} 04^{\prime} 04^{\prime \prime} \mathrm{N}$ & $35^{\circ} 27^{\prime} 18^{\prime \prime} \mathrm{E}$ \\
\hline & 7 & Israel_Raihaniya & $33^{\circ} 03^{\prime} 01^{\prime \prime} \mathrm{N}$ & $35^{\circ} 29^{\prime} 10^{\prime \prime} \mathrm{E}$ \\
\hline & 8 & Israel_Kash & $33^{\circ} 01^{\prime} 47^{\prime \prime} \mathrm{N}$ & $35^{\circ} 29^{\prime} 26^{\prime \prime} \mathrm{E}$ \\
\hline & 9 & Israel_Jahudha & $32^{\circ} 56^{\prime} 42^{\prime \prime} \mathrm{N}$ & $35^{\circ} 36^{\prime} 49^{\prime \prime} \mathrm{E}$ \\
\hline & 10 & Israel_Sasa & $33^{\circ} 01^{\prime} 58^{\prime \prime} \mathrm{N}$ & $35^{\circ} 23^{\prime} 30^{\prime \prime} \mathrm{E}$ \\
\hline & 11 & Israel_Kziv & $33^{\circ} 02^{\prime} 40^{\prime \prime} \mathrm{N}$ & $35^{\circ} 14^{\prime} 38^{\prime \prime} \mathrm{E}$ \\
\hline & 12 & Israel_Manof & $33^{\circ} 50^{\prime} 58^{\prime \prime} \mathrm{N}$ & $35^{\circ} 13^{\prime} 52^{\prime \prime} \mathrm{E}$ \\
\hline \multirow[t]{10}{*}{ Central Israel } & 13 & Israel_Hedera & $32^{\circ} 26^{\prime} 29^{\prime \prime} \mathrm{N}$ & $34^{\circ} 54^{\prime} 09^{\prime \prime} \mathrm{E}$ \\
\hline & 14 & Israel_Gaash & $32^{\circ} 13^{\prime} 39^{\prime \prime} \mathrm{N}$ & $34^{\circ} 49^{\prime} 31^{\prime \prime} \mathrm{E}$ \\
\hline & 15 & Israel_Herzelia & $32^{\circ} 11^{\prime} 22^{\prime \prime} \mathrm{N}$ & $34^{\circ} 48^{\prime} 30^{\prime \prime} \mathrm{E}$ \\
\hline & 16 & Israel_Afeka & $32^{\circ} 07^{\prime} 06^{\prime \prime} \mathrm{N}$ & $34^{\circ} 49^{\prime} 21^{\prime \prime} \mathrm{E}$ \\
\hline & 17 & Israel_Hulon A & $32^{\circ} 01^{\prime} 08^{\prime \prime} \mathrm{N}$ & $34^{\circ} 47^{\prime} 40^{\prime \prime} \mathrm{E}$ \\
\hline & 18 & Israel_Hulon B & $32^{\circ} 00^{\prime} 07^{\prime \prime} \mathrm{N}$ & $34^{\circ} 45^{\prime} 31^{\prime \prime} \mathrm{E}$ \\
\hline & 19 & Israel_Shafadan & $31^{\circ} 56^{\prime} 30^{\prime \prime} \mathrm{N}$ & $34^{\circ} 44^{\prime} 42^{\prime \prime} \mathrm{E}$ \\
\hline & 20 & Israel_Palmahim & $31^{\circ} 55^{\prime} 52^{\prime \prime} \mathrm{N}$ & $34^{\circ} 42^{\prime} 26^{\prime \prime} \mathrm{E}$ \\
\hline & 21 & Israel_Bet-Zayit & $31^{\circ} 46^{\prime} 55^{\prime \prime} \mathrm{N}$ & $35^{\circ} 09^{\prime} 39^{\prime \prime} \mathrm{E}$ \\
\hline & 22 & Israel_Jerusalem-Mammilla & $31^{\circ} 46^{\prime} 34^{\prime \prime} \mathrm{N}$ & $35^{\circ} 13^{\prime} 25^{\prime \prime} \mathrm{E}$ \\
\hline \multirow[t]{4}{*}{ Southern and eastern Israel } & 23 & Israel_Gidron Mount & $32^{\circ} 06^{\prime} 37^{\prime \prime} \mathrm{N}$ & $35^{\circ} 29^{\prime} 25^{\prime \prime} \mathrm{E}$ \\
\hline & 24 & Israel_Naaran & $31^{\circ} 54^{\prime} 26^{\prime \prime} \mathrm{N}$ & $35^{\circ} 28^{\prime} 04^{\prime \prime} \mathrm{E}$ \\
\hline & 25 & Israel_Ein-Fara (Wadi Kelt) & $31^{\circ} 49^{\prime} 43^{\prime \prime} \mathrm{N}$ & $35^{\circ} 20^{\prime} 15^{\prime \prime} \mathrm{E}$ \\
\hline & 26 & Israel_Hazeva & $30^{\circ} 46^{\prime} 03^{\prime \prime} \mathrm{N}$ & $35^{\circ} 16^{\prime} 42^{\prime \prime} \mathrm{E}$ \\
\hline \multirow[t]{4}{*}{ Sites outside of Israel } & 27 & Egypt_Amerya & $31^{\circ} 00^{\prime} 49^{\prime \prime} \mathrm{N}$ & $29^{\circ} 49^{\prime} 22^{\prime \prime} \mathrm{E}$ \\
\hline & 28 & Turkey_Bahsili karaahmetli & $39^{\circ} 39^{\prime} 41^{\prime \prime} \mathrm{N}$ & $33^{\circ} 25^{\prime} 01^{\prime \prime} \mathrm{E}$ \\
\hline & 29 & Iran_Qarea Ziya Eddin & $38^{\circ} 53^{\prime} 20^{\prime \prime} \mathrm{N}$ & $45^{\circ} 09^{\prime} 53^{\prime \prime} \mathrm{E}$ \\
\hline & 30 & Germany_Kovlant & $50^{\circ} 21^{\prime} 35^{\prime \prime} \mathrm{N}$ & $07^{\circ} 35^{\prime} 52^{\prime \prime} \mathrm{E}$ \\
\hline
\end{tabular}

The 30 breeding sites comprise 26 breeding sites in Israel and four sites in other countries: Egypt, Turkey, Iran, and Germany. 
stressful environments. Liu et al. (2000) described the relationships of Asian bufonids using partial sequences of mitochondrial (mt)DNA genes and found that East Asian bufonids were grouped into two major clades. One clade included Bufo andrewsi, Bufo bankorensis, Bufo gargarizans, Bufo tibetanus, Bufo tuberculatus, its sister clade Bufo cryptotympanicus, and two species of the Torrentophryne. The second clade consisted of Bufo galeatus, Bufo himalayanus, Bufo melanostictus, and a new species from Vietnam.

In a study of mtDNA gene sequences of Bufo bufo, Igawa et al. (2006) estimated the divergence time in order to clarify the evolutionary relationships and biogeography of toads distributed in the Far East and Europe. Masta et al. (2003) studied the structuring of genetic variability in the true toad, Bufo woodhousei, populations of which exhibited a low but significant geographical substructuring of populations according to a microsatellite analysis. Smith and Green (2004) studied the phylogeographical structure of genetic variability in Fowler's toads (Bufo fowleri) at the northern edge of its distribution, where its range encircles the Lake Erie basin. Using a 540-bp sequence from the mitochondrial control region, they found that the phylogeographical pattern was very complex.

Jaeger et al. (2005) observed geographical distributions of Bufo punctatus in western North America according to mtDNA; he found that the geographical distributions of clades had little overlap and corresponded to the general boundaries of the peninsular desert (in the east) and continental desert (in the west) regions separated geographically along the Rocky Mountains and Sierra Madre Occidental.

To further expand the information mentioned above, in the current study, we examined genetic molecular variations within and among populations located in different parts of Israel, characterized by different climates and existing under extreme conditions. Results of this study contribute to the current knowledge of genetic adaptations of $P$. viridis to various conditions. This information on genetic variations and diversity among different regions in Israel, where the climate and ecological conditions vary dramatically from Mediterranean to desert conditions, is important to understanding the potential for the wide distribution of this species.

\section{Methods}

This study was approved by the Society for the Protection of Nature in Israel (SPNI).

\section{Sites studied}

In order to analyze and characterize genetic differences among individuals from different breeding sites, one to five tissue samples were obtained from tadpole or adult

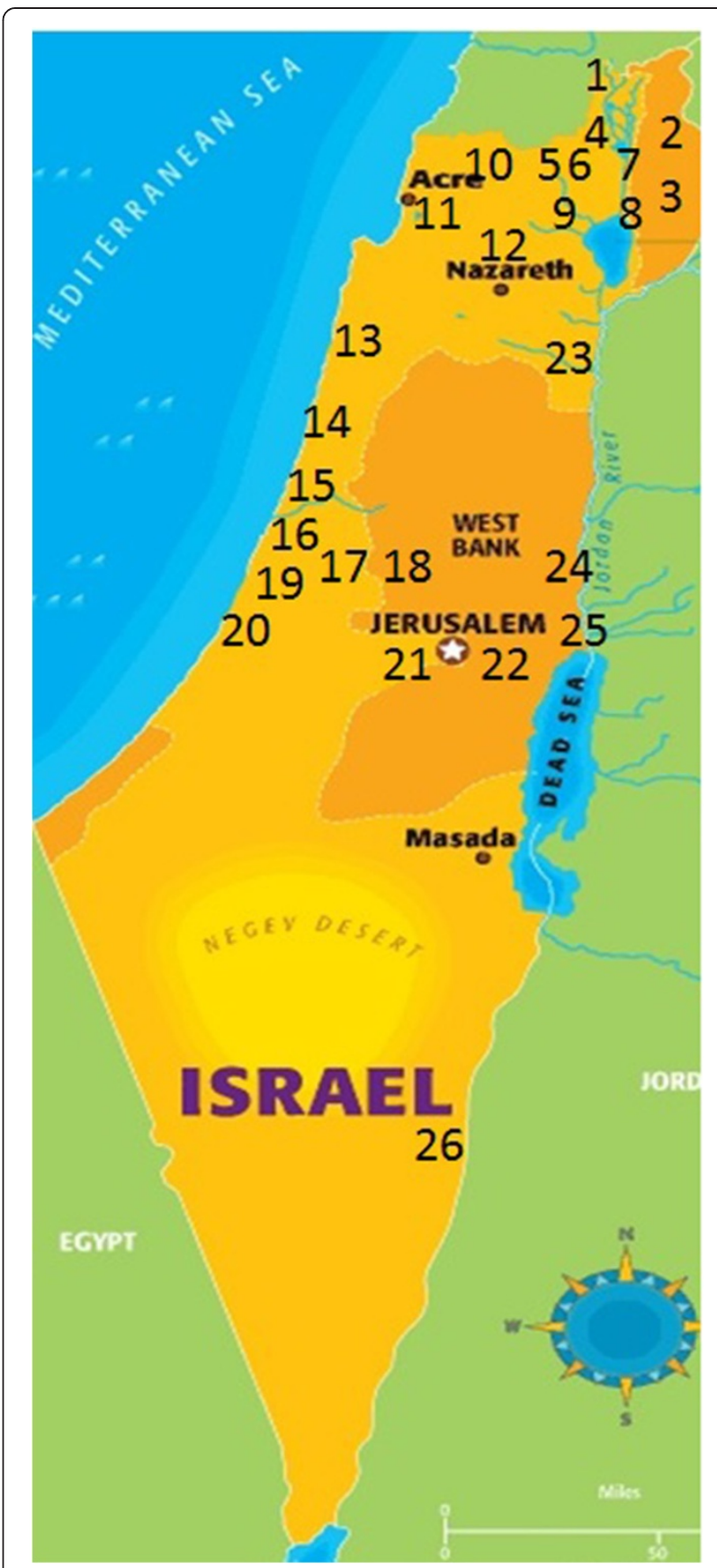

Figure 1 Distribution of $P$. viridis populations examined in the current study. Numbers on the map indicate different sites where samples were collected (site names and locality information are given in Table 1). Northern Israel (Mount Hermon, Galilee, and Golan Heights): (1) Mount Hermon, (2) Masade, (3) Orvim, (4) Nahalit, (5) Fara, (6) Matityahu, (7) Raihaniya, (8) Kash, (9) Jahudha, (10) Sasa, (11) Kziv, and (12) Manof. Central Israel (coastal region and Judean mountains): (13) Hadera, (14) Gaash, (15) Herzelia, (16) Afeka, (17) Hulon A, (18) Hulon B, (19) Shafdan, (20) Palmahim, (21) Bet-Zayit, and (22) Jerusalem (Mamila). Southern and eastern Israel (Jordan Valley, Negev, and Arava): (23) Mount Gidron, (24) Naaran, (25) Ein-Fara (Wadi Kelt), and (26) Hazeva. 
Table 2 Primers used to amplify the mitochondrial conserved region, Cyt $b$, mitochondrial D-loop, and RAPD analysis

\begin{tabular}{llll}
\hline Analysis & Primer & Sequence 5'-3' & Reference \\
\hline Cyt $b$ & CB2Xen-H & CCCTCAAAAAGATATTTGTCCTCA & Palumbi et al. (2002) \\
& MVZ43L & GAGTCTGCCTWATYGCYCARAT & Graybeal (1993) \\
D-loop & ContBH & GTCCATTGGAGGTTAAGATCTACCA & Goebel et al. (1999) \\
& ContL & CTAACGTTCACGAAGATGGAA & Goebel et al. (1999) \\
RAPD & OPA2 & TGCCGAGCTG & Mikulicek and Pialek (2003) \\
\hline
\end{tabular}

$P$. viridis individuals from 26 different natural breeding sites throughout the range of $P$. viridis in Israel. The areas included northern Israel, Mount Hermon, the Golan Heights, and Galilee (sites 1 to 12 ), the coastal plains and Dan area (sites 13 to 22), and Judea, as well as more southern and eastern deserts surrounding Israel (sites $23 \sim 26$ ) (Table 1, Figure 1). In addition, we used three to five tissue samples of $P$. viridis from Egypt, Turkey, Iran, and Germany (one site per country) as out-group populations (Table 1).

\section{Sample collection and DNA extraction}

Sample tissue was taken by nonlethal tail clipping (generally $<1 \mathrm{~cm}$ in total length) from dip-net-captured larvae. Adult toad specimens were randomly sampled by hand from the entire water body area and from the area around the ponds. We collected tissue samples from adult toads by clipping one finger from the front leg and immediately storing it in 95\% ethanol until it was transferred to an ultracold freezer $\left(-80^{\circ} \mathrm{C}\right)$. Total genomic DNA was extracted from a piece of tadpole tail or toe-clipped tissue, using the QIAamp DNA Mini Kit (Qiagen, Hilden, Germany) after proteinase $\mathrm{K}$ digestion. The DNA extraction methods used were as described by Goldberg et al. (2009b).

\section{DNA amplification, sequencing, and analysis}

We tested 28 D-loop and cytochrome $b$ (Cyt $b$ ) populations (population numbers 1 to 8 and 11 to 30 are in Table 1) amplified with primers ContBH and ContJL (Goebel et al. 1999) and primers CB2Xen and MVZ43L (Graybeal 1993; Palumbi et al. 2002), respectively (Table 2; for an explanation of DNA amplification, sequencing, and analyses, see Goldberg et al. 2009b).

\section{Random amplified polymorphic DNA amplification and analysis}

Random amplified polymorphic DNA (RAPD) polymerase chain reaction (PCR) amplification was carried out with the random primer, OPA-2 (Mikulicek and Pialek 2003; Table 2), which was selected from several primers tested. Seventy-six samples of 21 populations (population numbers 1 to 3,6 to 20, and 23 to 25; Table 1) were run in a single gel in order to prevent the effect of the method on variations (for an explanation of RAPD amplification and analyses, see Goldberg et al. 2011).

\section{Amplified fragment length polymorphism amplification and analysis}

Eighty-six samples of 24 populations (population numbers $1,2,5,7$ to $18,20,22$ to 25 , and 27 to 30 ; Table 1 ) were tested for amplified fragment length polymorphism (AFLP) analysis. Genomic DNA was digested with EcoRI and MseI, and then selective amplification was perfor med using six primer combinations: Mse-CAC/EcoACG, Mse-CAC/Eco-ACT, Mse-CTT/Eco-ACT, MseCAC/Eco-ACC, Mse-CTT/Eco-ACC, and Mse-CTG /Eco-ACC (Table 3).

The AFLP protocol was carried out following the procedure described by Vos et al. (1995) with some modifications. High-quality genomic DNA $(0.5 \mu \mathrm{g} / \mu \mathrm{l})$ was digested with a pair of restriction enzymes (EcoRI/MseI) at $37^{\circ} \mathrm{C}$ for $3 \mathrm{~h}$ and then ligated to double-stranded EcoRI and MseI adaptors using T4 DNA ligase.

\section{Variance and population structure analyses}

The variance analysis was performed on 3 levels of within populations, among populations, and among regions, based on the following division of the 26 Israeli sites: sites 1 to 12 in northern Israel (Mount Hermon, Golan Heights, and Galilee); sites 12 to 22 in central Israel (coastal region and Judean Hills), and sites 23 to 26 in southeastern Israel (Jordan Valley and Arava Valley). DNA sequences were analyzed using methods developed by Wilbur and Lipman (1983). Variances

Table 3 Primer combinations and number of polymorphic loci per combination used in AFLP analysis

\begin{tabular}{lllc}
\hline \multicolumn{3}{c}{ Marker } \\
\hline Locus & Unlabeled & Labeled & Number of scored polymorphic loci \\
\hline 1 & Mse-CAC & ECO-ACG & 90 \\
2 & Mse-CAC & ECO-ACT & 105 \\
3 & Mse-CTT & ECO-ACT & 93 \\
4 & Mse-CAC & ECO-ACC & 71 \\
5 & Mse-CTT & Eco-ACC & 79 \\
6 & Mse-CTG & ECO-ACC & 70 \\
Total & & & 508 \\
\hline
\end{tabular}


within populations, among populations, and among regions were obtained by comparing the Israeli sites and 4 out-groups. We used the DNASTAR software package (Wilbur and Lipman 1983) to calculate the DNA sequences.

In order to examine the distribution of variations and differential connectivity among populations (the proportion of the total variance among populations (PhiPT)), regions (the proportion of the total variance among regions (PhiRT)), and populations within regions (the proportion of the total variance among populations within regions (PhiPR)), we performed an analysis of molecular variance (AMOVA) with populations nested within regions, using GenAlEX (Peakall and Smouse 2006).

Population and regional pairwise PhiPT, PhiPR, and PhiRT values were also calculated in order to examine the distribution of differences within populations, between populations, and among geographical areas, respectively, and to describe the expected deviation of heterozygosity (Peakall and Smouse 2006). The value of $\mathrm{Nm}$, which refers to the movement of individuals among subpopulations in each generation (Slatkin 1985), was calculated using GenAlEx (Peakall and Smouse 2006). The genetic distance by Nei and Li's distance matrix (Nei 1972, 1978) and its statistical significance (by the exact test) were estimated using Tools for Population Genetic Analyses software (Miller 1997). The evolutionary history was inferred using the neighbor-joining (NJ) method (Saitou and Nei 1987). We used MEGA5 software (Tamura et al. 2011) to perform the phylogenetic analyses.

We analyzed DNA sequences using methods developed by Wilbur and Lipman (1983). The haplotype analysis was described by Peakall and Smouse (2006). To analyze the correlation between Nei's genetic distance (Nei 1978) and aerial distances (Veness 2011), we used the Mantel test (Mantel 1967). The Bayesian analysis of population structure (BAPS) was calculated according to Corander et al. (2008). We calculated the aerial distance $(\mathrm{km})$ among breeding sites according to latitude and longitude between each locality using the calculator on a website (Veness 2011).

\section{Results and discussion \\ Results \\ mtDNA sequencing results}

DNA sequences were analyzed from 269 bp of the D-loop and 262 bp of Cyt $b$. We found a $96.7 \%$ similarity index according to Wilbur and Lipman (1983) for the D-loop alignment between the $P$. viridis partial sequence and the $P$. viridis consensus fragment (GenBank accession no. AF190253; Liu et al. Liu et al. 2000) and a 97.3\% similarity index by Wilbur and Lipman for the Cyt $b$ alignment between the $P$. viridis partial sequence and the $P$. viridis consensus fragment (GenBank accession no. L10982; Graybeal 1993).

Genetic differences in the control region nucleotide sequences among $P$. viridis populations in Israel varied from $0 \%$ to $2.7 \%$ (Table 4 ), and differences of populations in Israel with populations outside of Israel (Egypt, Turkey, Iran, and Germany) varied from $1.2 \%$ to $8.2 \%$. The greatest differences of $7.0 \%$ to $8.2 \%$ were found between the German and Israeli populations (DNASTAR software package, Table 4).

Genetic differences in the Cyt $b$ nucleotide sequences (CBNSs) among populations in Israel varied from $0 \%$ to $3.5 \%$ (Table 4). Comparison of the Israeli populations

Table 4 Range of nucleotide variations of D-loop and Cyt $b$ fragments (DNASTAR software) in populations of $P$. viridis

\begin{tabular}{|c|c|c|c|}
\hline & \multirow[t]{2}{*}{ Site } & \multicolumn{2}{|c|}{$\begin{array}{l}\text { Percent variation among } \\
\text { populations in Israel }\end{array}$} \\
\hline & & Control region & Cyt $b$ \\
\hline 1 & Hermon & $0.6-2.4$ & $0-1.5$ \\
\hline 2 & Masade & $0-1.8$ & $0-2.5$ \\
\hline 3 & Orvim & $0-1.5$ & $0-2.5$ \\
\hline 4 & Nahalit & $0-1.5$ & $0-2.5$ \\
\hline 5 & Fara & $0.3-2.1$ & $0-2.5$ \\
\hline 6 & Matityahu & $0-1.8$ & $0-2.5$ \\
\hline 7 & Raihaniya & $0.3-1.5$ & $0-2.5$ \\
\hline 8 & Kash & $0-1.8$ & $0-2.5$ \\
\hline 11 & Kziv & $0.6-2.7$ & $0-3.5$ \\
\hline 12 & Manof & $0-1.8$ & $0-2.5$ \\
\hline 13 & Hedra & $0-1.8$ & $0-3.5$ \\
\hline 14 & Gaash & $0-1.8$ & $0-3.5$ \\
\hline 15 & Herzelia & $0.6-2.1$ & $0-2.5$ \\
\hline 16 & Afeka & $1.5-2.7$ & $0-2.5$ \\
\hline 17 & Hulon A & $0.3-2.1$ & $0-2.5$ \\
\hline 18 & Hulon B & $0.9-2.7$ & $0-2.5$ \\
\hline 19 & Shafadan & $0.6-2.4$ & $0-2.5$ \\
\hline 20 & Palmahim & $0-1.8$ & $0-3.5$ \\
\hline 21 & Bet-Zayit & $0-1.5$ & $0-2.5$ \\
\hline 22 & Jerusalem & $0.6-2.4$ & $0-2.5$ \\
\hline 23 & Gidron Mount & $0.3-1.5$ & $0-1.5$ \\
\hline 24 & Naaran & $0.3-2.4$ & $0-2.5$ \\
\hline 25 & Ein-Fara & $0.3-2.1$ & $0-2.5$ \\
\hline 26 & Hazeva & $0-1.8$ & $0.5-3.0$ \\
\hline 27 & Egypt_Amerya & $1.6-2.8$ & $3.0-5.5$ \\
\hline 28 & Turkey_Bahsili karaahmetli & $1.7-3.2$ & $0.5-3.0$ \\
\hline 29 & Iran_Qarea Ziya Eddin & $1.2-3.0$ & $0.5-3.0$ \\
\hline 30 & Germany_Kovlantz & $7.0-8.2$ & $3.0-5.5$ \\
\hline
\end{tabular}

There are 24 habitats in Israel and 4 habitats in other countries. Site numbers match numbers in Table 1. 
with populations outside of Israel (Egypt, Turkey, Iran, and Germany) yielded a CBNS average genetic variability range of $0.5 \%$ to $5.5 \%$; the greatest differences were found for Egyptian and German populations with Israeli populations of $3.0 \%$ to $5.5 \%$ (DNASTAR software package, Table 4).

Control region samples contained 30 haplotypes by GenAlEx (Peakall and Smouse 2006) (107 individuals); 21 of them contained individuals of one site each (haplotypes $1,2,4,7,9$ to $12,14,15,17,20$ to 25 , and 27 to
30). The other haplotypes included individuals from at least two different areas (Figure 2). Haplotypes 3, 5, and 8 accounted for about $50 \%$ of all samples. Haplotypes 3 and 8 were common in almost all regions of Israel, and haplotype 5 was more frequent in eastern populations. The out-group populations were only represented by independent haplotypes. These results did not suggest a clear geographic pattern.

The Cyt $b$ samples contained five haplotypes by GenAlEx (117 individuals; Figure 3). Haplotype 1 accounted for the

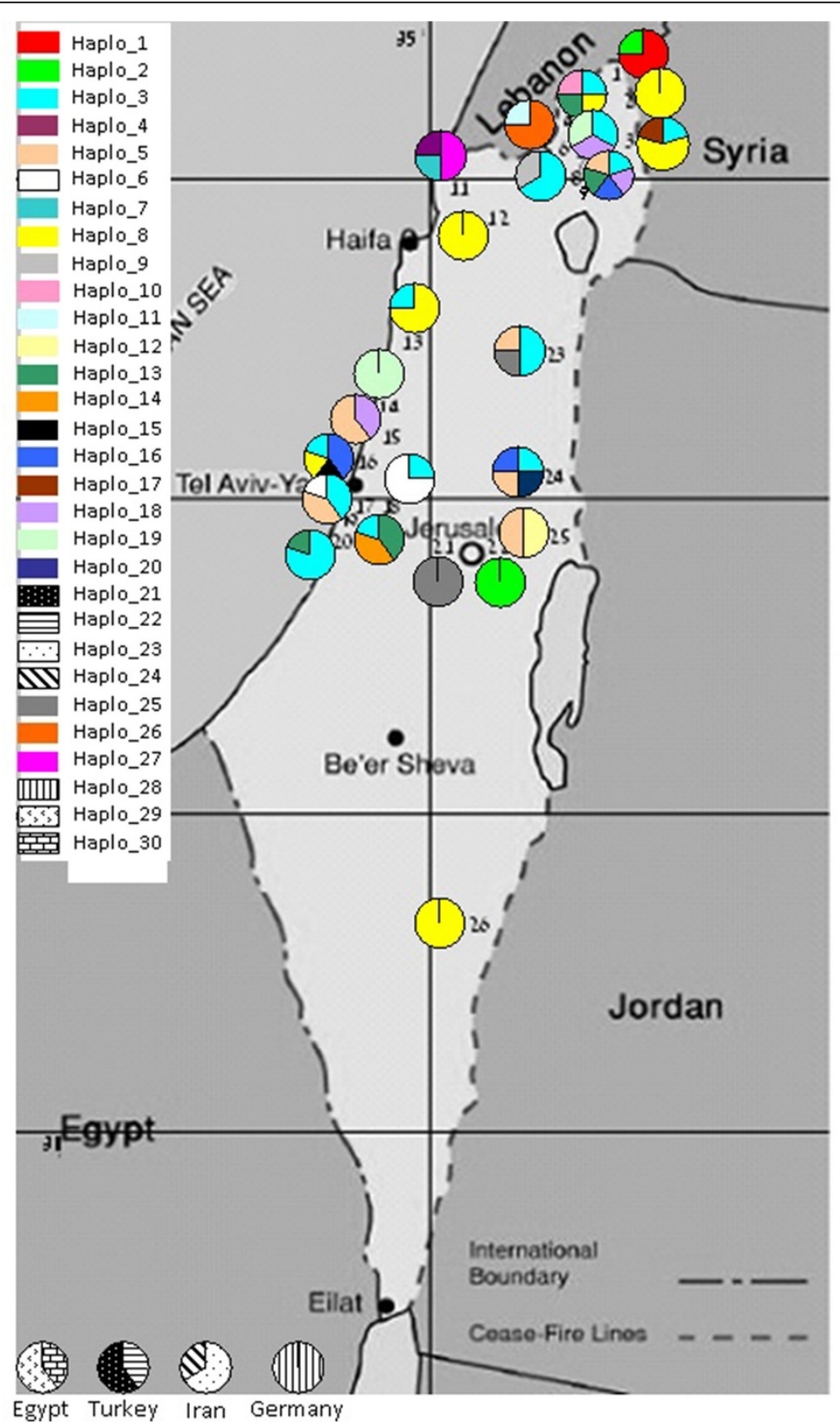

Figure 2 Haplotype frequencies of $P$. viridis populations across Israel according to the D-loop analysis. Site names and locality information are given in Table 1. 


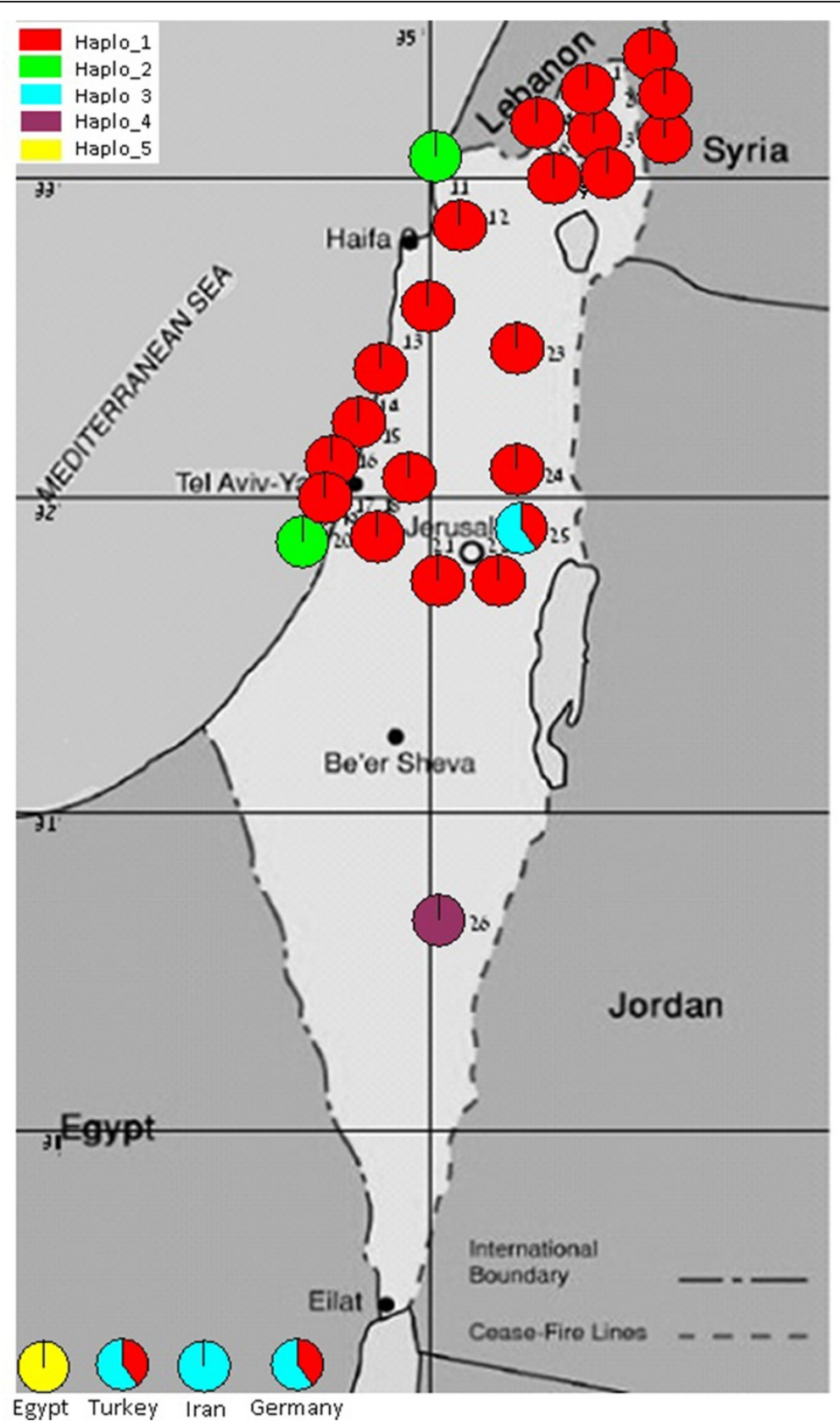

Figure 3 Haplotype frequencies of $\boldsymbol{P}$. viridis populations across Israel according to the Cyt $\boldsymbol{b}$ analysis. Site names and locality information are given in Table 1.

majority of individuals (76.9\%) and showed a joint distribution among populations from northern, central, and southern Israel. Haplotypes 2 and 3 were fixed among 13 and 10 individual sequences, respectively, and haplotypes 4 and 5 were contained in one sample each. Results of the Cyt $b$ fragments demonstrated a relatively small variation among $P$. viridis populations. However, the analysis of the Cyt $b$ sequences of the southernmost and easternmost populations (populations 25 and 26) differed from those of the other populations. Both of these populations had unique clusters that did not appear in others.

Nei's genetic distances of D-loop and Cyt $b$ fragments among Israeli $P$. viridis populations indicated a relatively small variation ( 0 to 0.35 distance; Figures 4 and 5). Comparison of sites outside and within Israel revealed significant differences, especially between Egyptian specimens and Israel populations, even though Egypt was not the most distant country examined. 


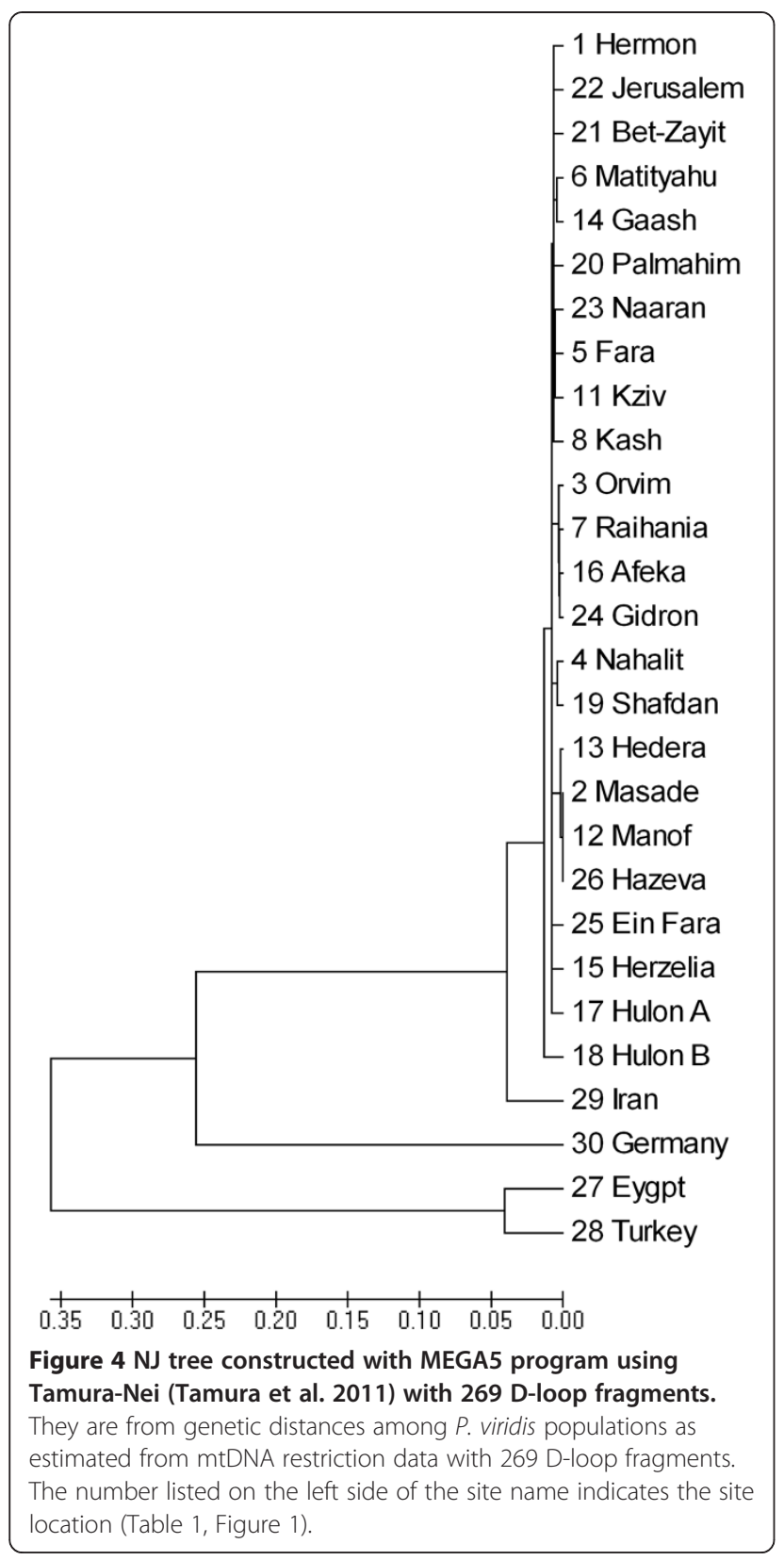

We used the AMOVA test to examine variations of $P$. viridis among populations, within populations, and among regions. The analysis of Israeli sites showed a molecular variance of $0 \%$ in the D-loop and Cyt $b$ fragments among regions. Among populations in Israel, there were high levels of variation (93\%) in the Cyt $b$ fragment and $26 \%$ in the D-loop. Within populations in Israel, there was a high level of variation in the D-loop (74\%) and a low level of variation (7\%) in the Cyt $b$ fragment (Table 5 parts A and B). Comparison of Israeli sites with four out-groups according to the D-loop and Cyt $b$ fragments revealed molecular variances of $73 \%$ and $72 \%$, respectively, among regions; $5 \%$ and $24 \%$, respectively, among populations; and $22 \%$ and $4 \%$, respectively, within populations (Table 5 parts $C$ and D). Values of PhiRT for Israeli sites were relatively low, and they were not statistically significant. However, the comparison of Israeli sites with the out-group populations yielded higher values. All values of PhiPR and PhiPT in both the Israeli sites and out-group populations were statistically significant.

The number of migrants obtained was 0.024 to 1.459 . High numbers of migrants per generation indicated either recurrent gene flow or past historical associations among them. We found no significant correlation with geographical distances among the D-loop and Cyt $b$ fragments using Nei's genetic distances (Nei 1978; Table 6).

\section{RAPD analysis results}

RAPD samples had the highest number of unique groups, with a total of 45 haplotypes in the 76 individuals sampled. The other 13 haplotypes were contained in two or three individual samples, where one half included individuals from two different areas and the other one half contained individuals from one area. An unusual case was that of haplotype 12, which included two individuals, one from the northernmost population (population 1) and the other from one of the southernmost populations (population 25). Results of the RAPD analysis demonstrated a relatively high level of variation among $P$. viridis populations.

We performed a cluster analysis based on Nei's unbiased genetic distance (Nei 1978), using the NJ method. The analysis indicated two main groups of $P$. viridis populations and demonstrated a relatively low level of variation ( 0 to 0.15 distance). One subgroup of populations consisted of seven populations that were mostly edge populations. This subgroup included the northernmost population (site 1 in Figure 1) and three populations near the southern and eastern deserts surrounding Israel (sites 23, 24, and 25 in Figure 1).

Variance components among regions, among populations, and within populations detected with AMOVA using GenAlEx were $4 \%, 34 \%$, and $62 \%$, respectively. Values of the PhiRT, PhiPR, and PhiPT were all statistically significant (Table 7 part A).

Results of the Mantel test (Mantel 1967) revealed no correlation between Nei's genetic distance (Nei 1978) and aerial distances (Veness 2011) (Table 6). Hence, geographical distances from northern to southern Israel had no apparent effect on genetic diversity.

\section{AFLP analysis results}

In total, 508 polymorphic amplicons (bands) were generated from five combinations of AFLP selective primers 


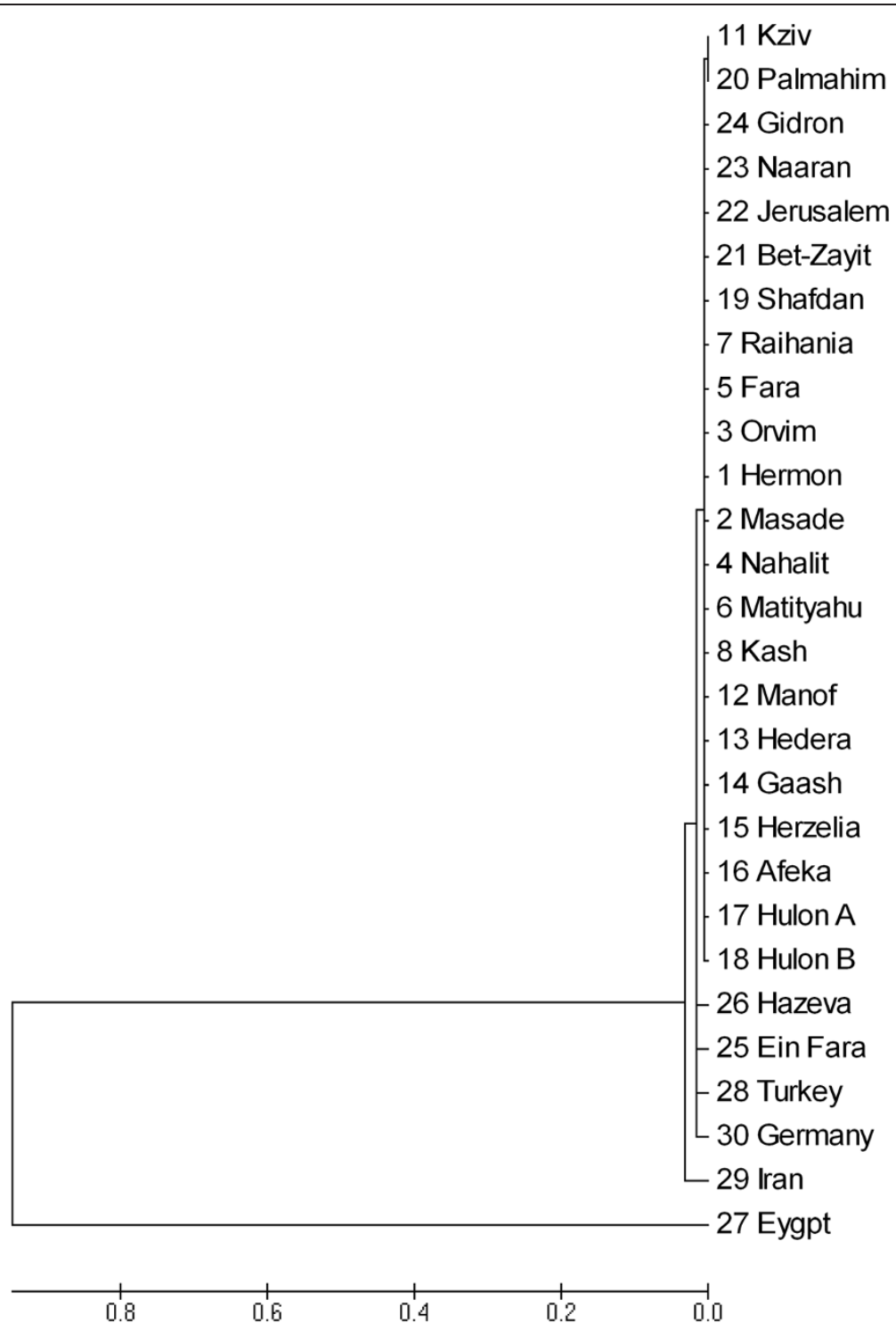

Figure 5 NJ tree constructed with MEGA5 program using Tamura-Nei (Tamura et al. 2011) with 262 Cyt $b$ fragments. They are from genetic distances among $P$. viridis populations as estimated from mtDNA restriction data with 262 Cyt $b$ fragments. The number listed on the left side of the site name indicates the site location on the map (Figure 1).

in 86 individuals. The number of scoreable polymorphic loci per marker varied from 70 to 105.

The individual cluster analysis using BAPS defined all individuals in a single cluster, which meant that all individuals were found to be similar to each other and not different enough from other groups. The dendrogram presented in Figure 6 is based on the genetic distance coefficient matrix of all $P$. viridis individuals sampled. It reveals only moderate correlations with geographic location.

Results of the AMOVA test of $P$. viridis variations at Israeli sites among regions, among populations, and within populations using GenAlEx were $2 \%, 8 \%$, and $90 \%$, respectively (Table 7 part B), and those of the
Israeli sites plus four out-group populations were 69\%, $30 \%$, and $1 \%$, respectively (Table 7 part C). Values of PhiRT, PhiPR, and PhiPT were all statistically significant.

Among the 24 populations examined, the mean percentage of polymorphic loci, $H_{e}$, and $I$ values were $15.5 \%, 0.048$, and 0.074 , respectively. Site 25, Ein-Fara, a stable body of water in the Jordan Valley, had the highest level of variability (polymorphic loci ( $\% P$ ) of $23.0 \%, H_{e}$ of 0.067 , and $I$ of 0.106 ) among populations in Israel, whereas the Sasa population, an ephemeral breeding site, exhibited the lowest level of variability (\%P of 9.3\%, $H_{e}$ of 0.033 , and $I$ of 0.050 ). Among the out-groups, the population in Turkey had the highest level of variability (\%P of $26.4 \%, H_{e}$ of 0.077 , and $I$ of 0.122 ), and the 
Table 5 AMOVA for individuals of $P$. viridis from breeding sites based on D-loop and Cyt $b$ fragments

\begin{tabular}{|c|c|c|c|c|c|c|c|c|c|}
\hline Site part & & $d f$ & SS & MS & Est. var. & Total variance (\%) & Phi & $p$ value & $\mathrm{Nm}$ \\
\hline \multirow[t]{3}{*}{ (A) Israeli sites: control region } & Among regions & 2 & 4.37 & 2.18 & 0.0 & 0 & PhiRT 0.01 & 0.800 & 1.459 \\
\hline & Among populations & 19 & 51.01 & 2.69 & 0.39 & 26 & PhiPR 0.27 & 0.010 & \\
\hline & Within populations & 70 & 75.13 & 1.07 & 1.07 & 74 & PhiPT 0.26 & 0.010 & \\
\hline \multirow[t]{3}{*}{ (B) Israeli sites: Cyt b } & Among regions & 2 & 0.90 & 0.45 & 0.0 & 0 & PhiRT 0.09 & 1.000 & 0.039 \\
\hline & Among populations & 19 & 18.77 & 0.99 & 0.22 & 93 & PhiPR 0.93 & 0.010 & \\
\hline & Within populations & 76 & 1.20 & 0.02 & 0.02 & 7 & PhiPT 0.92 & 0.010 & \\
\hline \multirow{3}{*}{$\begin{array}{l}\text { (C) Israeli sites }+4 \text { out-group } \\
\text { populations: control region }\end{array}$} & Among regions & 6 & 357.36 & 59.56 & 4.70 & 73 & PhiRT 0.73 & 0.010 & 0.143 \\
\hline & Among populations & 19 & 51.01 & 2.68 & 0.30 & 5 & PhiPR 0.17 & 0.020 & \\
\hline & Within populations & 79 & 112.87 & 1.43 & 1.43 & 22 & PhiPT 0.78 & 0.010 & \\
\hline \multirow{3}{*}{$\begin{array}{l}\text { (D) Israeli sites + } 4 \text { out-group } \\
\text { populations: Cyt } b\end{array}$} & Among regions & 6 & 58.81 & 9.80 & 0.65 & 72 & PhiRT 0.72 & 0.010 & 0.024 \\
\hline & Among populations & 19 & 18.77 & 0.99 & 0.21 & 24 & PhiPR 0.84 & 0.010 & \\
\hline & Within populations & 89 & 3.60 & 0.04 & 0.04 & 4 & PhiPT 0.96 & 0.010 & \\
\hline
\end{tabular}

AMOVA for individuals of $P$. viridis from breeding sites in Israel (parts $A$ and $B$ ) and from four sites in other countries (parts $C$ and $D$ ), based on the control region and Cyt $b$ fragments. $p$ value estimates were based on 999 permutations. $d f$, degrees of freedom; SS, sum of squared observations; MS, mean of squared observations; Est. var., estimated variance; PhiPT, proportion of the total genetic variance among individuals within populations; PhiRT, proportion of the total genetic variance among regions; PhiPR, proportion of the total genetic variance among populations within regions.

population in Egypt had the lowest level of variability (\%P of $12.0 \%, H_{e}$ of 0.041 , and $I$ of 0.063 ). The Mantel test (Mantel 1967) revealed a positive correlation between pairwise genetic distances (Nei 1978) and their geographic distances (Veness 2011) (Table 8).

\section{Discussion}

The contribution of this study to the current knowledge of Bufo populations is the information it provides on genetic variations and diversity among various habitats throughout Israel, where ecological conditions dramatically vary from Mediterranean to desert conditions. Data collected from Israel were compared with data from different countries (Egypt, Turkey, Iran, and Germany), with different climates.

Characterizing the genetic structure of populations in extreme habitat conditions and examining how these taxa compare to species in moister habitats will help us better understand how organismal biology and environmental variations interact to shape the distribution of genetic diversity among amphibian populations. All 4 types of markers obtained, D-loop, Cyt $b$, RAPD, and AFLP, suggested that $P$. viridis individuals from different

Table 6 Mantel test using GenAlEx

\begin{tabular}{lcc}
\hline Analysis & Correlation $(\boldsymbol{r})$ & $\boldsymbol{p}$ value \\
\hline D-loop & 0.06 & 0.22 \\
Cyt b & 0.02 & 0.30 \\
RAPD & 0.05 & 0.27 \\
AFLP & 0.32 & $<0.01$
\end{tabular}

Tested if genetic distances between pairs of $P$. viridis populations were significantly correlated with corresponding geographical distances. Cyt, cytochrome, RAPD random amplified polymorphic DNA AFLP amplified fragment length polymorphism. localities in Israel were not completely differentiated, because they shared clusters between 2 or 3 regions and a relatively low level of variation by $P$. viridis population classifications (Figures 2, 3, 4, 5, and 6). In addition, the AMOVA test of Israeli sites using the D-loop, RAPD, and AFLP indicated that most of the variation was due to within-population variance $(74 \%, 62 \%$, and $90 \%$, respectively; Table 7 parts A and B).

However, a pattern of grouping based on habitat conditions of breeding sites and not on geographic location was revealed by clustering the D-loop and Cyt $b$ fragment sequences using the NJ method (Nei 1978; Figures 4 and 5). Subpopulations clustered by both the D-loop and Cyt $b$ fragments indicated that the four sites outside of Israel (Egypt, Turkey, Iran, and Germany) were a separate group. Egypt's population differed more than populations from the other three countries, even though, geographically, Egypt is the country closest to Israel.

Similar clustering was shown by the dendrogram based on RAPD genetic distances (Figure 6), which includes edge populations from Israel (populations 1, 9, 11, 20, and 23 to 25), which may be subject to a milder climatic regime.

Two distinct populations of $P$. viridis were found by haplotype frequency analysis of Cyt $b$ at Ein-Fara (population 25) and Hazeva (population 26). These two populations, respectively located in the Jordan Valley and the Arava, represent habitats with extreme climate and stressful environments. Haplotype frequencies of the Ein-Fara and Hazeva populations differed from those of the other populations. Ein-Fara also had a unique cluster according to the haplotype frequency analysis of the D-loop. 
Table 7 AMOVA for individuals of $P$. viridis from breeding sites based on RAPD and AFLP analyses

\begin{tabular}{|c|c|c|c|c|c|c|c|c|}
\hline Site part & & $d f$ & SS & MS & Est. var. & Total variance (\%) & Phi & $p$ value \\
\hline \multirow[t]{3}{*}{ (A) Israeli sites: RAPD } & Among regions & 2 & 13.46 & 6.73 & 0.09 & 4 & PhiRT 0.04 & 0.010 \\
\hline & Among populations & 18 & 77.0 & 4.33 & 0.80 & 34 & PhiPR 0.36 & 0.010 \\
\hline & Within populations & 55 & 79.83 & 1.45 & 1.45 & 62 & PhiPT 0.38 & 0.010 \\
\hline \multirow[t]{3}{*}{ (B) Israeli sites: AFLP } & Among regions & 2 & 86.74 & 43.37 & 0.53 & 2 & PhiRT 0.02 & 0.010 \\
\hline & Among populations & 17 & 523.20 & 30.78 & 2.06 & 8 & PhiPR 0.08 & 0.010 \\
\hline & Within populations & 52 & 1217.0 & 23.40 & 23.40 & 90 & PhiPT 0.10 & 0.010 \\
\hline \multirow{3}{*}{$\begin{array}{l}\text { (C) Israeli sites }+4 \text { out-group } \\
\text { populations: AFLP }\end{array}$} & Among regions & 3 & 37.79 & 12.60 & 0.56 & 69 & PhiRT 0.69 & 0.010 \\
\hline & Among populations & 20 & 17.83 & 0.89 & 0.24 & 30 & PhiPR 0.96 & 0.010 \\
\hline & Within populations & 62 & 0.58 & 0.01 & 0.01 & 1 & PhiPT 0.99 & 0.010 \\
\hline
\end{tabular}

AMOVA for individuals of $P$. viridis from breeding sites in Israel (parts A and B) and from four sites in other countries (part C) based on RAPD and AFLP analyses. $p$ value estimates are based on 999 permutations. $d f$ degrees of freedom, SS sum of squared observations, MS mean of squared observations, Est var estimated variance, PhiPT proportion of the total genetic variance among individuals within populations, PhiRT proportion of the total genetic variance among regions, PhiPR proportion of the total genetic variance among populations within regions.

The results reported here are consistent with those of Nevo et al. (1975) and Dessauer et al. (1975), who presented evidence based on differential gene frequencies of 12 populations of $P$. viridis in Israel and on the Vis Adriatic Island. Those findings suggested that natural selection was the major operating evolutionary force causing population differentiation. Furthermore, green toads probably demonstrate an adaptive strategy for high heterozygosity in accordance with their ecologically variable range in space and time. While gene flow may be continuous in central and marginal populations of green toads where bodies of water are interconnected, it must have completely stopped in isolated populations of the Jordan Valley, Negev, Arava, and Sinai Desert.

Thus, despite the different climatic conditions in areas from which $P$. viridis individuals were sampled, there was little effect on the genetic molecular level, and the results of the current study demonstrate a relatively low level of variation between $P$. viridis populations in northern and central Israel.

$P$. viridis is a relatively large terrestrial species, with a high rate of colonization of various habitats, e.g., ponds, springs, and pools (Elron et al. 2005). Individuals can travel considerable distances during their $4 \sim 5$-year lifespan (Langton 1989). In addition, tadpoles have the ability to adapt to very different breeding places with unpredictable conditions (Cummingham and Cherry 2004). It is expected that strong selection pressure in breeding sites with unpredictable conditions (in contrast to stable sites) will quickly fill the population with lineages of better-fit individuals, simply because their survival probability is higher than that of intermediate-fit solutions. Accordingly, it is expected that populations in predictable environments will have a higher percentage of polymorphisms than do populations in unpredictable environments. These results do not match those of Nevo and Beiles (1991), who found that tropical amphibian species were more heterozygous than temperate species ( $H=0.096$ vs. 0.065 , respectively; $p<0.001$ ). Their analysis was based on proteins (allozymes) and on larger samples than those in the current study.

Chan and Zamudio (2009) characterized the genetic structure of populations of two anurans (the Great Plains toad Anaxyrus cognatus and Couch's spadefoot toad Scaphiopus couchii) in the deserts of the US Southwest. They found limited genetic differentiation in both species, even between populations in adjacent valleys separated by dispersal barriers such as mountainous habitats. Their hypothesis was that stochasticity in the availability of appropriate breeding sites together with landscape homogeneity may have resulted in increased population connectivity in desert-adapted frogs. This study supports the hypothesis that various ecological conditions in a relatively small area have little effect on genetic variations, but relatively greater molecular variations were found at greater distances, e.g., in comparison with populations from different countries. Comparisons with other species in Israel showed that Salamandra infraimmaculata (Goldberg et al. 2009a), Triturus vittatus vittatus (Pearlson and Degani 2007, 2008; Pearlson et al. 2010), and Pelobates syriacus (Munwes et al. 2010) were more stable and did not have as high a migration rate as was found in $P$. viridis that used different winter pools (Degani and Kaplan 1999).

Comparisons between $P$. viridis populations in Israel and in other countries supported the argument that a great geographical distance between populations might not necessarily be correlated with greater genetic variation between populations (Figures 4 and 5). Genetic variability and the geographical distribution of $P$. viridis were intensively studied in Israel and in other parts of the world (Liu et al. 2000; Stock et al. 2005, 2006, 2008; Batista et al. 2006; Colliard et al. 2010). Batista et al. (2006) analyzed 35 individuals from widespread populations for 

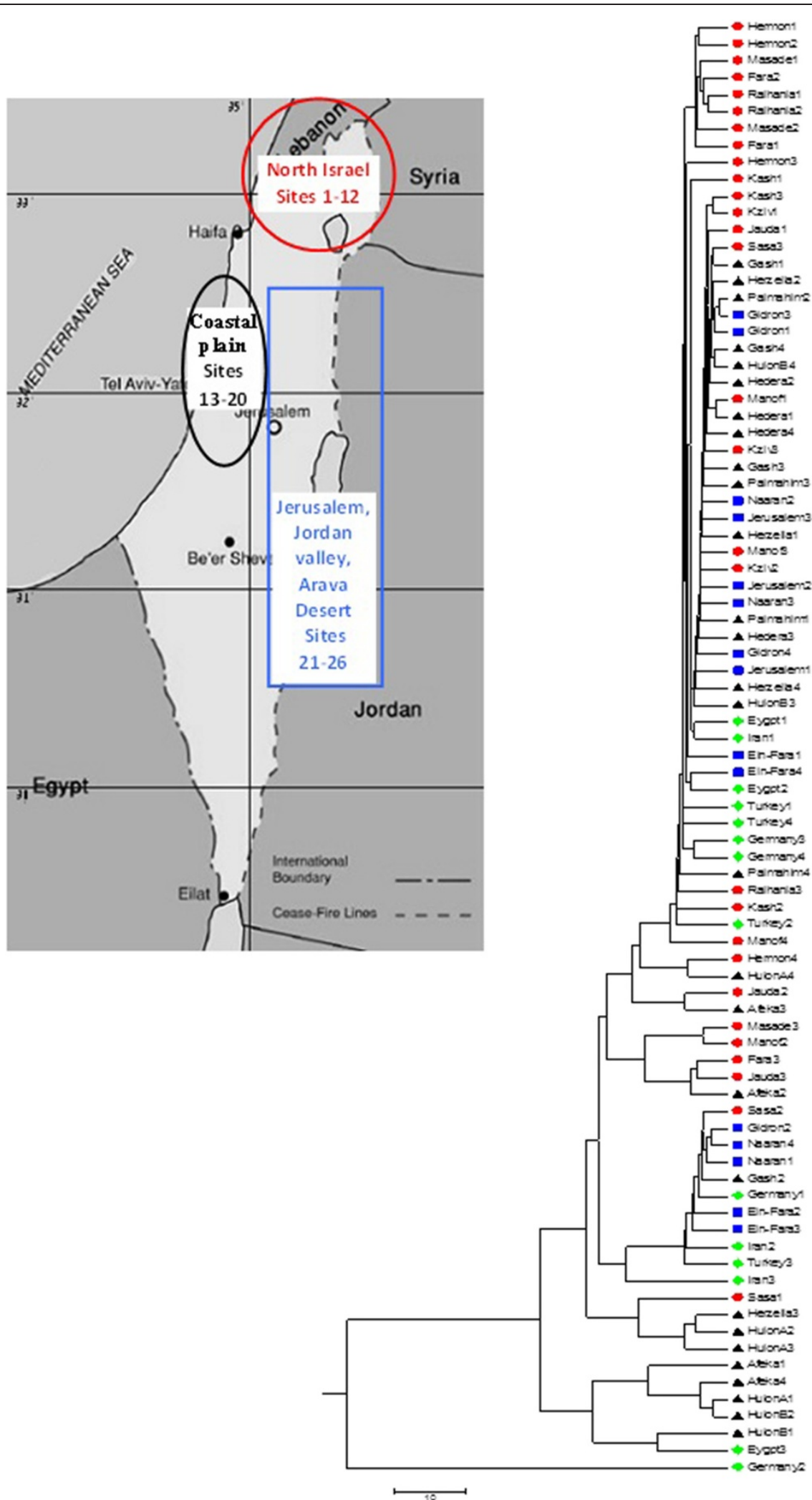

Figure 6 (See legend on next page.) 
(See figure on previous page.)

Figure 6 Dendrogram of genetic relatedness of $P$. viridis individuals sampled constructed with MEGA5 program (Tamura et al. 2011). They are estimated from the AFLP analysis of 508 polymorphic loci. The number listed on the right side of the site name indicates the individual number of each population sampled. The symbol on the left side of the site name represents the region in Israel: red circle, northern Israel (sites 1 to 12), black triangle, central Israel (sites 13 to 20), blue square, southern and eastern Israel (sites 21 to 26), and green diamond, sites outside of Israel (sites 27 to 30 ).

partial $12 \mathrm{~S}$ and $16 \mathrm{~S}$ ribosomal (r)RNA mtDNA. Three divergent lineages were determined: one in North Africa and Sicily, another in Europe, and a third in Sardinia and Mallorca. This was higher than typical intraspecific variations in Asian bufonids but lower than interspecific divergences (5\% 8\%; Liu et al. 2000).

Pearlson and Degani (2007) and Pearlson et al. (2010) found genetic variations between T. v. vittatus larvae from northern and central Israel using D-loop and Cyt $b$ genetic markers. Herein, the different mitochondrial markers showed different results, consistent with other studies on molecular variations among amphibian populations (Degani et al. 1999; Pearlson and Degani 2007;
Goldberg et al. 2009b). Moreover, analyses using different methods might also have affected the results.

The extensive similarity of $P$. viridis populations in Israel implies a long-term absence of barriers to gene flow in an otherwise discontinuously distributed population. However, epigenetic regulatory mechanisms must also be considered in order to account for possible adaptations to considerably different habitats without changing the DNA sequence.

Epigenetics is the study of heritable changes in gene function that occur without a change in the sequence of nuclear DNA. This form of inheritance allows the transmission of information from mother to daughter cell

Table 8 Descriptive statistical analysis of polymorphic AFLP loci of $P$. viridis from various breeding sites

\begin{tabular}{|c|c|c|c|c|c|c|c|c|c|}
\hline \multicolumn{2}{|c|}{ Breeding sites } & \multirow{2}{*}{$\begin{array}{l}n \\
4\end{array}$} & \multirow{2}{*}{$\begin{array}{c}\boldsymbol{N}(\mathrm{SE}) \\
3.862(0.015)\end{array}$} & \multirow{2}{*}{$\begin{array}{c}\boldsymbol{N}_{\boldsymbol{a}} \text { (SE) } \\
0.402(0.035)\end{array}$} & \multirow{2}{*}{$\begin{array}{c}\boldsymbol{N}_{\boldsymbol{e}} \text { (SE) } \\
1.087(0.009)\end{array}$} & \multirow{2}{*}{$\begin{array}{c}I \text { (SE) } \\
0.092(0.008)\end{array}$} & \multirow{2}{*}{$\begin{array}{c}\boldsymbol{H}_{\boldsymbol{e}} \text { (SE) } \\
0.058(0.005)\end{array}$} & \multirow{2}{*}{$\begin{array}{c}\mathrm{UH}_{\mathbf{e}} \text { (SE) } \\
0.067(0.006)\end{array}$} & \multirow{2}{*}{$\begin{array}{l}\% P \\
19.7\end{array}$} \\
\hline 1 & Hermon & & & & & & & & \\
\hline 2 & Masade & 3 & $2.705(0.020)$ & $0.234(0.027)$ & $1.055(0.008)$ & $0.053(0.007)$ & $0.035(0.005)$ & $0.042(0.006)$ & 10.0 \\
\hline 5 & Fara & 3 & $2.844(0.016)$ & $0.283(0.030)$ & $1.068(0.009)$ & $0.064(0.008)$ & $0.042(0.005)$ & $0.051(0.006)$ & 12.2 \\
\hline 7 & Raihaniya & 3 & $3.000(0.000)$ & $0.358(0.033)$ & $1.096(0.010)$ & $0.090(0.009)$ & $0.059(0.006)$ & $0.071(0.007)$ & 16.9 \\
\hline 8 & kash & 3 & $3.000(0.000)$ & $0.398(0.035)$ & $1.099(0.010)$ & $0.099(0.009)$ & $0.064(0.006)$ & $0.077(0.007)$ & 19.7 \\
\hline 9 & Jahudha & 3 & $2.705(0.020)$ & $0.215(0.027)$ & $1.056(0.008)$ & $0.054(0.007)$ & $0.036(0.005)$ & $0.044(0.006)$ & 10.4 \\
\hline 10 & Sasa & 3 & $2.502(0.022)$ & $0.189(0.026)$ & $1.053(0.008)$ & $0.050(0.007)$ & $0.033(0.005)$ & $0.041(0.006)$ & 9.3 \\
\hline 11 & Kziv & 3 & $3.000(0.000)$ & $0.230(0.028)$ & $1.054(0.007)$ & $0.056(0.007)$ & $0.036(0.005)$ & $0.043(0.005)$ & 11.2 \\
\hline 12 & Manof & 4 & $3.705(0.020)$ & $0.407(0.028)$ & $1.083(0.008)$ & $0.091(0.008)$ & $0.057(0.005)$ & $0.066(0.006)$ & 20.1 \\
\hline 13 & Hedera & 4 & $4.000(0.000)$ & $0.266(0.030)$ & $1.049(0.006)$ & $0.056(0.007)$ & $0.034(0.004)$ & $0.039(0.005)$ & 13.0 \\
\hline 14 & Gaash & 4 & $3.817(0.017)$ & $0.262(0.030)$ & $1.054(0.007)$ & $0.059(0.007)$ & $0.037(0.004)$ & $0.039(0.005)$ & 13.0 \\
\hline 15 & herzelia & 4 & $4.000(0.000)$ & $0.266(0.030)$ & $1.049(0.006)$ & $0.056(0.007)$ & $0.034(0.004)$ & $0.039(0.005)$ & 13.0 \\
\hline 16 & Afeka & 4 & $3.136(0.041)$ & $0.396(0.035)$ & $1.091(0.009)$ & 0.092 & $0.059(0.0$ & 0.0 & 19.1 \\
\hline 17 & Hulon A & 4 & $3.301(0.033)$ & $0.400(0.035)$ & $1.098(0.010)$ & $0.097(0.009)$ & $0.063(0.006)$ & $0.074(0.007)$ & 19.5 \\
\hline 18 & Hulon B & 4 & $3.270(0.035)$ & $0.262(0.030)$ & $1.058(0.007)$ & $0.061(0.007)$ & $0.038(0.005)$ & $0.046(0.006)$ & 12.8 \\
\hline 20 & Palmahim & 4 & $4.000(0.000)$ & $0.360(0.034)$ & $1.069(0.007)$ & $0.078(0.008)$ & $0.048(0.005)$ & $0.055(0.005)$ & 17.9 \\
\hline 22 & Jerusalem & 3 & $3.000(0.000)$ & $0.272(0.034)$ & $1.065(0.007)$ & $0.067(0.008)$ & $0.043(0.005)$ & $0.051(0.006)$ & 13.4 \\
\hline 23 & Gidron & 4 & $3.817(0.017)$ & $0.217(0.027)$ & $1.041(0.006)$ & $0.046(0.006)$ & $0.029(0.004)$ & $0.033(0.004)$ & 10.6 \\
\hline 24 & Naaran & 4 & $3.634(0.034)$ & $0.293(0.031)$ & $1.053(0.006)$ & $0.062(0.007)$ & $0.038(0.004)$ & $0.044(0.005)$ & 14.6 \\
\hline 25 & Ein-Fara & 4 & $3.634(0.034)$ & $0.469(0.037)$ & $1.100(0.009)$ & $0.106(0.009)$ & $0.067(0.006)$ & $0.079(0.007)$ & 23.0 \\
\hline 27 & Egypt & 3 & $2.616(0.022)$ & $0.264(0.029)$ & $1.065(0.008)$ & $0.063(0.008)$ & $0.041(0.005)$ & $0.051(0.006)$ & 12.0 \\
\hline 28 & Turkey & 4 & $3.817(0.017)$ & $0.537(0.039)$ & $1.117(0.010)$ & $0.122(0.009)$ & $0.077(0.006)$ & $0.089(0.007)$ & 26.4 \\
\hline 29 & Iran & 3 & $2.457(0.035)$ & $0.321(0.032)$ & $1.085(0.010)$ & $0.079(0.009)$ & $0.052(0.006)$ & $0.064(0.007)$ & 14.8 \\
\hline 30 & Germany & 4 & $3.132(0.031)$ & $0.362(0.034)$ & $1.091(0.010)$ & $0.089(0.009)$ & $0.058(0.006)$ & $0.069(0.007)$ & 17.5 \\
\hline \multicolumn{2}{|c|}{ Average } & 3.6 & $3.282(0.006)$ & $0.320(0.002)$ & $1.073(0.002)$ & $0.074(0.002)$ & $0.048(0.001)$ & $0.056(0.001)$ & $15.5(0.91)$ \\
\hline
\end{tabular}

Number ( $n$ ) of individuals sampled per population for AFLP analysis: $N, N_{a}, N_{e}, I, H_{e}, U_{e}$ and \%P. 
without the information being encoded in the nucleotide sequence of the gene (Trasler 2009). At present, epigenetics includes DNA methylation, histone variants and their post-translational modifications, and interactions of microRNAs with the genome (Mager and Bartolomei 2005).

The induction of phenotypic variations by stress during development may also be part of a strategy in which variants are produced in anticipation that some of these variants will be adaptive. These variants might only have a single-generation advantage when the epigenetic changes are restricted to somatic cells. If, however, an epigenetic change occurs in the germ line, then it is transmitted to subsequent generations. This generation of new phenotypes is a 'lottery approach', meaning that most of these phenotypes are not adaptive. However, the gamble may provide a chance to escape from severe environmental bottlenecks (Hamdoun and Epel 2007).

\section{Conclusions}

In conclusion, the current study focuses on genetic variations among different populations located in Israel under extremely different climates. Analysis of the three molecular markers, D-loop, Cyt $b$, and RAPD, indicated a high level of genetic similarity in Israeli green toads, except for the ecogeographical edge populations from Mount Hermon and the desert. Less clear results were obtained by the AFLP analysis, probably due to the low number of individuals sampled (Medina et al. 2006), as it is clear today that the greater the genetic variability among individuals in a particular area, the larger the sample size needed to capture it. The small size of samples examined in the present study of bufonids in Israel should be increased in future studies in order to identify the true ecogeographical correlates of bufonids.

\section{Competing interests}

The authors declare that they have no competing interests.

\section{Authors' contributions}

GD and EN designed the experiment. TG, AG, and EE carried out the sampling in Israel. TG analyzed the data as well as made figures and tables. GD and TG wrote the paper. TG, EN, AG, and EE finalized the manuscript. All authors read and approved the final manuscript.

\section{Author details \\ ${ }^{1}$ MIGAL, Galilee Technology Center, Kiryat Shmona 11016, Israel. ${ }^{2}$ School of Science and Technology, Tel-Hai College, Upper Galilee 12210, Israel. ${ }^{3}$ Department of Zoology, George S. Wise Faculty of Life Sciences, Tel Aviv University, Tel Aviv 69978, Israel. ${ }^{4}$ Institute of Evolution, Faculty of Sciences and Science Education, University of Haifa, Haifa 31905, Israel.}

Received: 17 July 2012 Accepted: 19 February 2013 Published: 30 September 2013

\section{References}

Baskale E, Sayim F, Yildirim S, Atatür MK, Kaya U (2011) Reproductive ecology and body size-fecundity relationships of the green toad, Pseudepidalea viridis (Laurenti, 1768), in the Kocaçay Stream, Izmir, Turkey. Zool Mid East 52:39-46
Batista V, Carranza S, Carretero MA, Harris DJ (2006) Genetic variation within Bufo viridis: evidence from mitochondrial 125 and 165 rRNA DNA sequences. Bull Soc Catalana d'Herpetol 17:24-33

Blaustein L, Margalit J (1995) Spatial distribution of Culiseta longiareolata (Culicidae: Diptera) and Bufo viridis (Amphibia: Bufonidae) among and within desert pools. J Arid Environ 29:199-211

Chan LM, Zamudio KR (2009) Population differentiation of temperate amphibians in unpredictable environments. Mol Ecol 18:3185-3200

Colliard C, Sicilia A, Turrisi GF, Arculeo M, Perrin N, Stöck M (2010) Strong reproductive barriers in a narrow hybrid zone of West-Mediterranean green toads (Bufo viridis subgroup) with Plio-Pleistocene divergence. BMC Evol Biol 10:232

Corander J, Marttinen P, Siren J, Tang J (2008) Enhanced Bayesian modeling in BAPS software for learning genetics structures of populations. Bioinformatics 9:539-552

Cummingham M, Cherry I (2004) Molecular systematics of African 20-chromosome toads (Anura: Bufonidae). Mol Phylogen Evol 32:671-685

Degani G (1982) Amphibian tadpole interaction in a winter pond. Hydrobiol 96:3-8

Degani G (1986) Growth and behavior of six species of amphibian larvae in a winter pond in Israel. Hydrobiol 140:5-10

Degani G, Kaplan D (1999) Distribution of amphibian larvae in Israeli habitats with changeable water availability. Hydrobiol 405:49-56

Degani G, Jackson K, Dosoretz C, Plotzky Y (1999) Molecular DNA variation in Salamandra infraimmaculata from different habitats. Israel J Zool 44:239-246

Dessauer HC, Nevo E, Chuang KC (1975) High genetic variability in an ecologically variable vertebrate, Bufo viridis. Biochem Genet 13:651-661

Disi A, Amr Z (2010) Morphometrics, distribution and ecology of amphibians in Jordan. Vertebr Zool 60:147-162

Duellman W (1993) Amphibian species of the world: additions and corrections. Publishers of the Museum of Natural History. University of Kansas, Kansas

Elron E, Gasith A, Gafny S (2005) Increased occupancy of the green toad (Bufo viridis), a possible syndrome of a population in trouble. Israel J Zool 51:63

Goebel AM, Donnelly JM, Atz ME (1999) PCR primers and amplification methods for 125 ribosomal DNA, the control region, cytochrome oxidase I, and cytochrome $b$ in bufonids and other frogs, and an overview of PCR primers which have amplified DNA in amphibians successfully. Mol Phylogen Evol 11:163-199

Goldberg T, Nevo E, Degani G (2009a) Breeding site selection according to suitability for amphibian larval growth under various ecological conditions in the semi-arid zone of northern Israel. Ecol Mediterr 35:65-74

Goldberg T, Pearlson O, Nevo E, Degani G (2009b) Sequence analysis of mitochondrial DNA in Salamandra infraimmaculata larvae from populations in northern Israel. South Am J Herpetol 4:268-274

Goldberg T, Degani G, Gazith A, Elron E, Nevo E (2011) Sequence variation in the mitochondrial DNA of Pseudepidalea viridis (Syn. Bufo viridis) in Israel, Bulletin UASVM animal science and biotechnologies. Bulletin of University of Agricultural Sciences and Veterinary Medicine Cluj-Napoca 68(1-2):51-57

Graybeal A (1993) The phylogenetic utility of cytochrome $b$ : lessons from bufonid frogs. Mol Phylogen Evol 2:256-269

Hamdoun A, Epel D (2007) Embryo stability and vulnerability in an always changing world. Proc Natl Acad Sci USA 104:1745-1750

Igawa T, Kurabayashi A, Nishioka M, Sumida M (2006) Molecular phylogenetic relationship of toads distributed in the far east and Europe inferred from the nucleotide sequences of mitochondrial DNA genes. Mol Phylogen Evol 38:250-260

Jaeger JR, Riddle BR, Bradford DF (2005) Cryptic Neogene vicariance and quaternary dispersal of the red-spotted toad (Bufo punctatus): insights on the evolution of North American warm desert biotas. Mol Ecol 14:3033-3048

Katzmann S, Waringer-Löschenkohl A, Waringer A (2003) Effects of inter- and intraspecific competition on growth and development of Bufo viridis and Bufo bufo tadpoles. Limnologica 33:122-130

Langton TES (1989) Reasons for preventing amphibian mortality on roads. In: Langton TES (ed) Amphibians and roads. Proceedings of the Toad Tunnel Conference, Rendsburg, 7-8 January 1989. ACO Polymer Products, Rendsburg, pp 75-80

Liu W, Lathrop A, Fu J, Yang D, Murphy RW (2000) Phylogeny of East Asian bufonids inferred from mitochondrial DNA sequences (Anura: Amphibia). Mol Phylogen Evol 14:423-435

Mager J, Bartolomei MS (2005) Strategies for dissecting epigenetic mechanisms in the mouse. Nat Genet 37:1194-2000

Mantel N (1967) The detection of disease clustering and a generalized regression approach. Cancer Res 27:209-220 
Masta SE, Laurent NM, Routman EJ (2003) Population genetic structure of the toad Bufo woodhousii: an empirical assessment of the effects of haplotype extinction on nested cladistic analysis. Mol Ecol 12:1541-1554

Matsui M (1986) Geographic variation in toads of the Bufo bufo complex from the far east, with a description of a new subspecies. Copeia 1986:561-579

Medina RF, Barbosa P, Christman M, Battisti A (2006) Number of individuals and molecular markers to use in genetic differentiation studies. Mol Ecol Notes 6:1010-1013

Mikulicek P, Pialek J (2003) Molecular identification of three crested newt species (Triturus cristatus superspecies) by RAPD markers. Amphibia-Reptilia 24:201-207

Miller MP (1997) Tools for population genetic analyses (TFPGA). Department of Biological Sciences, Northern Arizona University, Flagstaff

Munwes I, Geffen E, Roll U, Friedmann A, Daya A, Tikochinski Y, Gafny S (2010) The change in genetic diversity down the core-edge gradient in the eastern spadefoot toad (Pelobates syriacus). Mol Ecol 19:2675-2689

Nei M (1972) Genetic distance between populations. Am Nat 106:283-292

Nei M (1978) Estimation of average heterozygosity and genetic distance from a small number of individuals. Genetics 89:583-590

Nevo E, Beiles A (1991) Genetic diversity and ecological heterogeneity in amphibian evolution. Copeia 3:565-592

Nevo E, Dessauert HC, Chuangt KC (1975) Genetic variation as a test of natural selection: allozymes/heterozygosity/environmental heterogeneity. Proc Nat Acad Sci USA 72:2145-2149

Newman RA (1992) Adaptive plasticity in amphibian metamorphosis. Biosci 42:42671-44678

Palumbi SR, Martin AP, Romano SL, McMillan WO, Stice L, Grabowski G (2002) The simple fool's guide to PCR, vers. 2.0. Department of Zoology and Kewalo Marine Laboratory, University of Hawaii, Honolulu

Peakall R, Smouse PE (2006) GenALEx 6: genetic analysis in excel. Population genetic software for teaching and research. Mol Ecol Notes 6:288-295

Pearlson O, Degani G (2007) Molecular DNA variations among Triturus vittatus vittatus (Urodela) from different breeding sites at the southern limit of its distribution. Acta Herpetol 2:69-77

Pearlson O, Degani G (2008) The life history of Triturus v. vittatus (Urodela) in various habitats. Asiatic Herpetol. Res 11:91-95

Pearlson O, Bluestein L, Snir S, Goldberg D, Degani G (2010) Molecular variation in Triturus vittatus vittatus (Urodela) from breeding sites near the southern extremity of its distribution revealed by DNA sequencing of mitochondrial cytochrome $b$ gene and control region. Curr Herpetol 29:11-22

Ren Z, Zhu B, Ma E, Wen J, Tu T, Cao Y, Hasegawa M, Zhong Y (2009) Complete nucleotide sequence and gene arrangement of the mitochondrial genome of the crab-eating frog Fejervarya cancrivora and evolutionary implications. Gene 441:148-155

Saitou N, Nei M (1987) The neighbor-joining method: a new method for reconstructing phylogenetic trees. Mol Biol Evol 4:406-425

Sicilia A, Lillo F, Zava B, Bernini F (2007) Breeding phenology of Bufo viridis Laurenti, 1768 in Sicily. Acta Herpetol 1:107-117

Slatkin M (1985) Gene flow in natural populations. Annu Rev Ecol Systemat 16:393-430

Smith MA, Green DM (2004) Phylogeography of Bufo fowleri at its northern range limit. Mol Ecol 13:3723-3733

Stock M, Steinlein C, Lamatsch DK, Schartl M, Schmid M (2005) Multiple origins of tetraploid taxa in the Eurasian Bufo viridis subgroup. Genetica 124:255-272

Stock M, Moritz M, Hickerson D, Frynta T, Dujsebayeva V, Eremchenko JR, Macey JR, Papenfuss TJ, Wake DB (2006) Evolution of mitochondrial relationships and biogeography of Palearctic green toads (Bufo viridis subgroup) with insights in their genomic plasticity. Mol Phylogen Evol 41:663-689

Stock M, Sicilia A, Belfiore NM, Buckley D, Lo Brutto S, Lo Valvo M, Arculeo M (2008) Post-Messinian evolutionary relationships across the Sicilian channel: mitochondrial and nuclear markers link a new green toad from Sicily to African relatives. BMC Evol Biol 8:56

Tamura K, Peterson D, Peterson N, Stecher G, Nei M, Kumar S (2011) MEGA5: molecular evolutionary genetics analysis using maximum likelihood, evolutionary distance, and maximum parsimony methods. Mol Biol Evol 28:2731-2739
Trasler JM (2009) Epigenetics in spermatogenesis. Mol Cell Endocrinol 306:33-36 Veness C (2011) Calculate distance, bearing and more between latitude/longi tude points, Movable type scripts. Movable Type Ltd, Cambridge, http://www.movable-type.co.uk/scripts. Accessed 4. January 2011

Vos P, Hogers R, Bleeker M, Reijans M, Van de Lee T, Hornes M, Friters A, Pot J, Paleman J, Kuiper M, Zabeau M (1995) AFLP: a new technique for DNA fingerprinting. Nucleic Acids Res 23:4407-4414

Wilbur WJ, Lipman DJ (1983) Rapid similarity searches of nucleic acid and protein data banks. Proc Natl Acad Sci USA 80:726-730

\section{doi:10.1186/1810-522X-52-18}

Cite this article as: Degani et al:: DNA variations of the green toad

Pseudepidalea viridis (syn. Bufo viridis) from various habitats. Zoological Studies 2013 52:18.

\section{Submit your manuscript to a SpringerOpen ${ }^{\circ}$ journal and benefit from:}

- Convenient online submission

- Rigorous peer review

- Immediate publication on acceptance

- Open access: articles freely available online

- High visibility within the field

- Retaining the copyright to your article

Submit your next manuscript at springeropen.com 